$$
\text { "szasz" — 2005/7/4 — 13:47 — page 35—\#1 }
$$

\title{
The mathematics textbook as an aid to differentiation: A first Hungarian example
}

\author{
István CzegléDy and RÉKA SzÁsz
}

\begin{abstract}
Differentiation is a way of teaching where each student is taught according to his/her personal needs. This technique is not widely used in Hungary yet, although this would be necessary due to the introduction of the two-level final examination and to a growing concern for equal opportunities and integrated teaching. One of the most significant aids to differentiation is an appropriate textbook, and that is why a group of professionals wrote a set of textbooks that supports this technique. The paper examines the requirements for a differentiated textbook, and the extent to which the textbook in question meets them.
\end{abstract}

Key words and phrases: differentiation, textbook secondary education.

ZDM Subject Classification: D40, U20.

\section{Introduction}

There is a diversity of students in each and every classroom: students differ in ability, aims, learning styles and many other factors. Hence teachers must adapt their teaching methods to the needs of individual students, which process is called differentiation. This means basically two things; one is using a variety of teaching styles, which ensures that each student profits from some of them. The other characteristic is a lesson where students do different kinds of tasks or proceed at a different pace. This latter feature poses several technical difficulties, as it is not easy for one teacher to teach several things at the same time. There

Copyright (c) 2005 by University of Debrecen
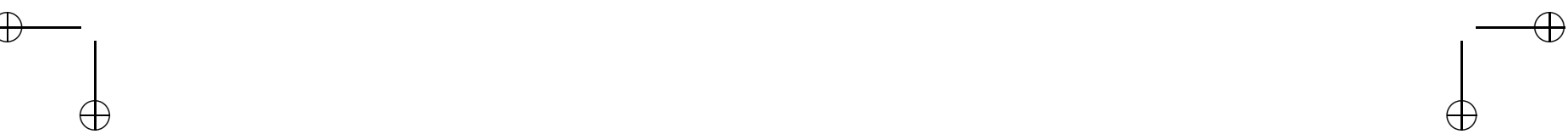
are many aids to ease the teacher's job in this situation, and one of the most important ones is the textbook.

In Hungary, differentiation has not been an issue until recently, although every teacher uses it intuitively to some degree. With increasing differences among students, the greater emphasis on equal opportunities, and the introduction of the two-level secondary final examination it is becoming a more and more acute need. In a statement about its programme for the integration of socially disadvantaged pupils, the Hungarian Ministry of Education claims that "integration (...) means applying organising techniques appropriate for differentiation" [1]. The need for differentiation led a group of mathematics educators to write the first Hungarian set of textbooks, Matematika (Mathematics, Czeglédy, Hajdu, Hajdu \& Kovács, [2]), with the motto "From remediation to enrichment" that provides for this method. The aim of this paper is to examine in what ways a textbook is able to facilitate differentiation, and to present and assess this first Hungarian attempt to write such a text. Section 2 talks about differentiation in general: motives, methods and curriculum. Section 3 focuses on the textbook itself, starts by a general description, then examines how it is built on a differentiated curriculum, provides for different methods of differentiation, and serves the needs of a diversity of students.

\section{Focus: Secondary school}

Although this textbook has been compiled for all years from 1 to 12 , the scope of this paper will be limited to secondary school (years 9 to 12). Here we must clarify the distinction between schools on secondary level ("középfokú iskola") in Hungary. Trade schools ("szakiskola" or "szakmunkásképző") prepare student for a trade, while secondary schools ("középiskola") prepare for the final examination ("érettségi"). These include vocational schools ("szakközépiskola"), which specialise in a certain profession, and grammar schools ("gimnázium"), which give a general education. Hence the textbook in question prepares for the final examination, and does not attempt to suit trade schools, where much less mathematics is taught.

\section{Differentiated teaching}

Differentiation as an answer to the diversity of students

Results of several surveys, such as the international PISA [3], and the national MONITOR [4] showed that variation in mathematical attainment has increased 
in Hungary. Besides, in another survey one of the authors has found that there is a striking difference in students' mathematics achievement not only between, but within classes, as well:

Table 1. Results of a national survey on mathematical competence [5]

\begin{tabular}{|l|c|c|c|c|c|}
\hline & $\begin{array}{c}\text { Excellent } \\
\mathbf{8 4 - 1 0 0 \%}\end{array}$ & $\begin{array}{c}\text { Good } \\
\mathbf{6 8 - 8 3 \%}\end{array}$ & $\begin{array}{c}\text { Average } \\
\mathbf{4 3 - 6 7 \%}\end{array}$ & $\begin{array}{c}\text { Weak } \\
\mathbf{2 0 - 4 2 \%}\end{array}$ & $\begin{array}{c}\text { Unacceptable } \\
\mathbf{0 - 1 9 \%}\end{array}$ \\
\hline School 1 & $6 \%$ & $53 \%$ & $35 \%$ & $6 \%$ & $0 \%$ \\
\hline School 2 & $2 \%$ & $12 \%$ & $28 \%$ & $23 \%$ & $36 \%$ \\
\hline School 3 & $2 \%$ & $5 \%$ & $29 \%$ & $38 \%$ & $26 \%$ \\
\hline School 4 & $9 \%$ & $9 \%$ & $39 \%$ & $28 \%$ & $15 \%$ \\
\hline School 5 & $0 \%$ & $0 \%$ & $9 \%$ & $40 \%$ & $51 \%$ \\
\hline School 6 & $0 \%$ & $9 \%$ & $11 \%$ & $34 \%$ & $46 \%$ \\
\hline School 7 & $0 \%$ & $19 \%$ & $46 \%$ & $30 \%$ & $5 \%$ \\
\hline School 8 & $30 \%$ & $28 \%$ & $24 \%$ & $13 \%$ & $5 \%$ \\
\hline
\end{tabular}

There are many factors underlying mathematical achievement, which educators need to bear in mind when trying to cope with the diversity of students [6]:

\section{Mathematical competence}

- mathematical ability

- cognitive stage

- prior mathematical learning

\section{Attitude towards mathematics}

- motivation

- self-confidence

\section{Way of learning}

- learning style

- study skills

- communication skills

\section{General factors}

- gender

- social background

- special needs 
An obvious answer to diversity is ability grouping, which is strongly present in Hungarian secondary schools. It is partly realized by way of entrance examinations, this way the ability and achievement level of students entering a certain secondary school is somewhat even; schools with difficult entry will take only high achievers, while those with an easier entry will attract low achieving students. In schools who can afford a class-division in mathematics, or in those who mix a whole age-group into several mathematics classes, the division is sometimes made according to mathematical achievement.

There are two reasons why ability grouping does not fully solve the problem of diversity. The first one is given by researchers who compared tracking (within school ability grouping) to mixed-ability classes. In 1982 Kulik \& Kulik [7] carried out a meta-analyis of 52 other studies investigating the effects of ability grouping. They found positive effects for high-ability, and near zero effects for average and below average students. However, in 1990 Slavin [8], carried out a meta-analysis of 29 studies. He found zero effects for all ability levels when all other factors were held constant, and explained previous positive findings about high-ability students by the greater number of classes they took. In addition, Boaler \& William [9] found tracking to cause a self-fulfilling prophecy through the self-image of students and the expectations of teachers, hence having a negative effect on students in lower tracks. It is also a concern of those interested in equal opportunities, that once a student is put in a weaker group or school (sometimes as soon as in primary school), it is practically impossible for him or her to get back into a stronger one. As Stiff ([10], p. 10) puts it, "my son, who is now in sixth grade, took his first college entrance exam at the end of first grade", meaning that, because he and his wife taught him a lot before school, he passed an exam to get into a special mathematics class for second grade, which resulted in being able to pass the exam for the special class again, a year later, and so on. As in this case, it is often social background and not ability that determines achievement initially, so this practice reinforces social inequalities [8].

The other reason why ability grouping does not solve the problem of student differences is that groups can never really be homogeneous. Although, as we stated before, students in a particular Hungarian secondary school are usually of similar ability and achievement, they are not selected at the entrance examination based solely on mathematics ability, but on many other factors. And even if a school does make further grouping for mathematics classes based on mathematical ability, students' ability within the group will still differ more or less, and they will certainly greatly differ in the other factors described before. 


$$
\text { "szasz" — 2005/7/4 — 13:47 — page } 39-\# 5
$$

In sum, it is not necessarily a good idea to group students according to ability, and even if we do, groups will still be somewhat heterogeneous. The usual principle teachers in Hungary use to handle differences is 'keep with the middle', which means addressing the needs of the average student in the class. This way, both high and low achievers tend to suffer, the former study less than they would be able to, the latter cannot keep with the pace and may fall behind irremediably [11]. And as we have emphasised before, students differ in many other factors than ability, so each of them needs a slightly different way of instruction. The alternative to teaching the whole class as a unit is differentiation, which is described below.

\section{Ways of differentiation}

Differentiation is 'the process of identifying, with each learner, the most effective strategies for achieving agreed targets' ([12], p. 129).

We can realize differentiation from the following aspects [6]:

\section{- Content}

Task

Pace of learning

Outcome

\section{- Way of learning}

Form of lesson

Teaching methods

Use of aids

\section{- Checking and assessment}

Differentiation by content means that students acquire the material at different levels. We can realize this by giving students tasks at different levels, or letting students proceed in the same material at different pace, or using openended questions that can have a different outcome, that is, they can be answered at different levels.

Differentiation by way of learning means using either different forms of lesson at the same time (i.e. doing frontal work with some students, while others work in groups, or individually), or different teaching methods within the same form of work. For example, the teacher may use a different form of dialogue (requiring a different level of independent thinking) with different individuals or groups. Individual work and homogenous grouping are also tools to differentiation by content. Grouping students heterogeneously realizes differentiation while 
students work on the same task, as they take different roles: more advanced students deepen their knowledge by explaining to their peers, while these benefit from their explanation. Students may also use different aids to solve tasks: some will need manipulatives, tables, or diagrams to answer a question, while others can solve the problem with abstract thinking. The teacher can also differentiate in the thoroughness of checking work. With some students they will content themselves with checking final results, with others looking at main steps is enough, while with some it is necessary to check work in detail. Finally, differentiation by content is usually accompanied with differentiation by assessment: if students learn different material they need to be assessed from different material, too.

Differentiation requires a great amount of attention and work from teachers, but there are certain tools they can make use of. It is essential to have an appropriate curriculum, which identifies core material, to be acquired by every student, and enrichment topics for those who are able to move faster [13] (the next section will discuss differentiated curriculum in detail). The most important help is a textbook that is built on the curriculum and takes every aspect of differentiation into consideration [13]. Other tools are assistant teachers (student teachers or volunteers) [14] and computers [15], which make all of the above mentioned aspects of differentiation easier.

Finally, as educators cannot differentiate all the time and in every aspect of teaching, they should teach in a way that is appropriate to a diversity of students. This means using a variety of instructional methods and materials [16] and real-life context which is able to bridge the gap between different students [10].

\section{Differentiated curriculum models}

Let us take a closer look at the differentiated curriculum. The National Council of School Mathematics of the USA outlines two types of curriculum models that can be used for differentiation, the Enrichment and the Differentiated Curriculum Models [13]. First, let us remark an issue in terminology. We are going to use the term differentiated curriculum for any curriculum allowing for differentiation. This can be based on several models, and one of these is called the Differentiated Curriculum Model. The word model will distinguish between the two terms.

The Enrichment Model consists of the same core material to be completed by all students, with additional, carefully selected material for student exploration. Students work on a particular content area, and those who move more 


$$
\text { "szasz" — 2005/7/4 — 13:47 — page } 41-\# 7
$$

quickly than the others complete the enrichment material in addition. After the allotted time period the entire class progresses to the next topic. Enrichment topics can fall into the following categories:

- Historical and cultural topics - taking more time to delve into the history and cultural contribution of topics

- Abstraction and generalization - addressing topics at a more abstract level

- New settings - looking at concepts in fresh settings

- New perspectives - gaining new perspectives and insights

- Deeper explorations - exploring relationships more deeply or exploring new relationships beyond those in the core

- Further examples of connections ([13], pp. 67-68)

In the Differentiated Model topics are addressed at various levels of concreteness and abstraction. Each topic starts with a core activity to be completed by all students, addressing some significant questions related to the new concept. These activities are on a concrete or semiconcrete level. After that the class discusses the key ideas and applications of the new concept. Then there are follow-up activities of different levels, so each students can proceed according to his/her own pace and ability.

The benefit from both models is flexibility. With each topic, every student can progress to his/her own maximum capacity, so slower students will have time to understand the core material thoroughly, while faster students can move on to more difficult topics. At the same time, it does not put students who complete lower level material at a certain topic to a disadvantage, as the class starts each topic together, and the extended material of one topic is never a prerequisite for that of another topic. Hence students who initially achieve lower due to family background or immaturity, for instance, have a chance to get to the forefront any time.

In the Hungarian secondary school the core material is determined by the core level requirements of the final examination, while enrichment and higher level topics can both include topics required for the extended level final examination, and other topics such as historical ones. Both models can be fully implemented in years 9 and 10. They are very effective in years 11 and 12, too, with the restriction that students who need to do an extended level final examination need to progress through all extended or higher level topics that are part of the extended level final examination requirements. 


\section{A differentiated textbook}

We stated before that the textbook is a crucial tool of differentiated teaching. We also described many features of differentiation, which set different requirements for the textbook. It has to be built on a differentiated curriculum, it has to provide for various methods of differentiation, and it has to be appropriate to a diversity of students. This section examines in what ways the first differentiated textbook written in Hungary, Matematika, (Czeglédy, Hajdu, Hajdu \& Kovács, [2]) suits these requirements. First, we shall briefly present the textbook itself.

\section{About the textbook}

The set of textbooks starts from year 1 and will last till year 12, at the moment it is finished up to year 11. For each secondary year, it includes a student's book, an answer book, a test booklet, an evaluation guide for tests, and a teacher's book. It conforms to the two-level final examination, and it includes both core and extended level material. In the students' book the extended material is indicated by a grey stripe on the margin, and problems are also colour coded according to difficulty and importance. They fall into three categories: easy, necessary and difficult. These categories do not correspond with being core or extended, as there are difficult problems in the core, and easy ones in the extended material. For this reason, the grey stripe is used with problems, too. The test booklet also indicates core and extended level problems. The teacher's book, among other things, gives guidance on how to differentiate. Groups with 3 or 4 lessons a week will probably cover mainly the core, while those with 5 hours will likely have a chance to master the extended material, too.

The students' book is divided into chapters according to main mathematical areas, and chapters are divided into sections presenting subtopics. Each section starts with a preliminary exercise, which makes students explore the skill to be taught. Those with not an evident solution are followed by a worked answer. After preliminary exercises the book presents new material: definitions, theorems, or procedures. Each of these is followed by worked exercises. The section ends with problems, colour-coded according to difficulty, as we have already explained. At the end of each chapter there is a chapter check which tests basic skills to have been acquired. Besides presenting the subscribed material of each year, the textbook provides an extra revision section at the beginning of the year 9 book, which covers the material of years $1-8$. 


$$
\text { "szasz" — 2005/7/4 - 13:47 - page } 43-\# 9
$$

The process of writing the textbook includes trying it in several classes, and adjusting it to student and teacher feedback. Classes from 10 different secondary schools participate in the study. A wide range of schools were selected: both comprehensive and vocational schools, from small towns to big cities, from schools with problematic students to elite ones. These classes use an unpublished copy of the textbook throughout their secondary mathematics studies, which is assessed every half year. Students give feedback through questionnaires concerning the textbook and mathematics lessons in general. Teacher feedback is asked through written evaluations, questionnaires, and notes made into their own copy of the textbook. Collection of written feedback is followed by a personal meeting with teachers every half year, where problematic issues are discussed. The authors use this information to adjust the content and the methods used before publishing the final copies. A similar system of evaluation will also be used before publishing future editions.

\section{Differentiated curriculum}

The textbook and the curriculum are strongly interconnected: as the textbook has strong influence on which skills are learned, it has to be strictly based on the curriculum to be used. In this case, the curriculum has to be two-fold: it has to provide a core material for all students, and an extended material for those aiming at the extended level final examination. In Section 2, we presented two suitable curriculum models, the enrichment and the differentiated ones, which are merged in this textbook. The core activity of both models consists of the preliminary exercises, the presentation of core material, and follow-up problems indicated as essential. Other follow-up activities, easy and difficult, should be individually selected for each student, or groups of students, which conforms to the differentiated model. Extended material is presented within sections, or in separate sections in the same way as the core, this is part of the enrichment topics of the enrichment model. As extended material also includes essential, easy and difficult problems, we can see a pattern of the differentiated model, again.

Let us look at some examples for the possible enrichment topics listed in Section 2. Historical and cultural topics are not part of the final examination requirements, but they are very important for several reasons. From the point of view of differentiation, their significance is being different from mathematical topics. Hence, they are likely to motivate many students, and also give a chance to excel to those who have better skills in social sciences than in mathematics. So historical and cultural topics were included in every chapter of the textbook, about 


$$
\text { "szasz" — 2005/7/4 - 13:47 — page } 44-\# 10
$$

lives of mathematicians, origin of mathematical words, application of mathematics such as golden section in arts, or history of mathematics, such as the Sumerian base 60 number system.

An example for abstraction and generalization in the textbook is the Binomial Theorem. The core material contains $(a+b)^{2}$ and $(a+b)^{3}$ as part of algebraic identities. As enrichment, the book explores higher powers of $(a+b)$, and it states and proves the general formula using Pascal's triangle and combinatorics.

The book teaches a concept in a new setting when dealing with the division of polynomials, for example. It starts from the concept of division in the usual setting of whole numbers, then it presents the same procedure in the new setting of polynomials.

New perspectives and deeper explorations are the most typical enrichment topics. An example for the first one is projections, extending isometries, the core material of geometric transformations. An instance of deeper exploration is quadratic equations. The core material is the quadratic formula and the sum and product of roots, and the enrichment material explores related propositions, such as sum and product of roots of quadratic equations with one root, and the factorised form of quadratic equations. Besides, deeper explorations include proofs of theorems that are omitted from the core, or problems requiring more complex thinking.

As connections with other subjects are included in historical and cultural topics by further examples of connections we mean connections within mathematics. Such is connecting the term concave in the geometrical and analytic sense, and emphasizing the similarities and differences between the two terms.

\section{Possibilities for differentiation}

With regards to content, the textbook obviously supports differentiation by task and by pace of learning due to the use and clear signalling of the differentiated curriculum. Both teachers and students appraised this feature:

Marking core and extended level parts with two different colours helps both

students and the teacher in finding their way about parts with different

levels of difficulty.

(a teacher)

Besides basic problems there are also more difficult ones, so everyone can

find the one suitable for themselves. (a year 11 student)

Differentiation by outcome is realized by open ended questions, such as
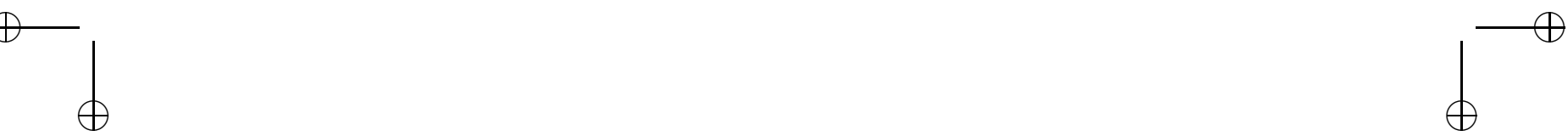


$$
\text { "szasz" — 2005/7/4 - 13:47 — page } 45 \text { - \#11 }
$$

Examine the above tessellations. Find as many congruencies as you can, by which the image pattern coincides with the original one.

([2], year 9, p. 213)

Construct the excircle and the incircle of an equilateral triangle. State your observations and conjectures.

([2], year 9, p. 288)

However, the number of such questions could be increased in the future.

The textbook helps differentiation by way of learning by the great number of worked examples in the first place. Hence students working individually or in groups can look at these even when the teacher is busy with others. Many students praised this feature:

I greatly appreciate this book, because I am weak in Science, but I learn much easier now due to explanations and precise working out of problems.

(a year 11 student)

Besides, the great umber of visual illustrations helps differentiation by aids possible, as every student finds the most suitable one for himself/herself.

Differentiation in checking answers is supported by an answer book, and differentiation by assessment is supported by a test booklet which contains tests at different levels, following the framework of the two-level final examination.

We have mentioned the computer as an important tool for differentiation; the textbook makes use of it by suggesting topics to be explored with the computer. We have also emphasised the importance of variety of teaching methods and real-life context. As the former is a more complex question, we will examine it in the next section, and here we show an example for the latter feature.

The average time difference between two generations in a family is 30 years. The Hungarian state was founded - under the reign of St. Stephen - about 33 generations ago.

$A$ person has 2 parents, $2 \times 2$ grandparents, $2 \times 2 \times 2$ great-grandparents, etc. Using this argument, estimate the number of your ancestors living at the time of the foundation of the Hungarian state.

Does this argument (mathematical model) reflects reality accurately?

([2], year 9, p. 39)

Serving a diversity of students

Here we examine if the textbook serves the needs of students varying in all of the factors described in Section 2. 
Competence in mathematics

With respect to mathematical ability, students in mainstream schools range from mildly mentally retarded to gifted. Due to the differentiated curriculum, the textbook should serve the needs of nearly all of them.

With mathematics teaching it is especially important to take Jean Piaget's theory on cognitive development into account. A secondary school student is supposed to be at the final, formal operational stage, where he is already able to reason with abstractions [17]. However, the age boundaries of the stages vary greatly, so there can be students still on the concrete operational stage. This might cause difficulties in mathematics for the student, but according to recent theories, appropriate education can help the student move to the next stage in a shorter time [18].

In order to suit students in different cognitive stages, the book builds each topic starting from the concrete, and gradually moving towards the abstract. As students proceed in the material as far as they can, each will learn it on the highest stage suitable for him/her. The gradual transition from concrete to abstract material will also quicken students' transition from one stage to another.

Differences in prior mathematical learning are the most significant after changing schools, which is usually the case at the beginning of year 9 . For this reason, the year 9 book starts with a revision chapter that includes all the mathematics material of the previous years. This ensures that all students start secondary school with a solid base of mathematical knowledge, and also helps the teacher pre-assess students' mathematics skills. Besides, this chapter also provides enrichment for those who need less revision than others.

\section{Attitude towards mathematics}

Motivation is the key to learning. Motivation can be intrinsic (inside) and extrinsic (outside). A student can be intrinsically motivated by an interest in mathematics, as Cangelosi ([19], p. 5) puts it "Adolescents' interest in mathematics ranges from obsessive avoidance to obsessive pursuit." Also, students differ in their interest outside mathematics, which teachers have to take into account when they want to set motivating contexts for them. Other intrinsically motivating factors are sense of achievement, affection for the teacher, an agreeable environment, and a possibility for choice. Extrinsic motivating factors are parent expectations and entrance into college or university. Depending on the subjects they need for their entrance, marks and knowledge of mathematics will have a different priority for students. 


$$
\text { "szasz" — 2005/7/4 - 13:47 — page } 47 \text { - \#13 }
$$

The authors of the book did their best to motivate students in many different ways. From a mathematical point of view, they included a great number of interesting exercises, and after a few students missed interesting puzzles, they added some of these, too. ("I think we learn much more interesting things from this experimental book than others", a year 9 student). To motivate those interested in non-mathematical subject matter, they included historical and cultural topics. ("I really like the stories", a year 10 student.) Sense of achievement is increased due to the differentiated curriculum, as everyone can feel they achieve their best, without frustration from too difficult, or boredom from too easy material. ("... I didn't believe that I could be better than a 4 . But I realised that by paying attention and understanding examples every problem can be solved.", a year 9 student.) The nice appearance of the book adds to the agreeable environment, and the differentiated curriculum provides for a chance of choice. It also increases extrinsic motivation by academic goals, as students feel they are preparing for the kind of examination they need for their future plans. ("I think it prepares us well for the final examination", a year 11 student).

It is a commonplace but it is specially true for mathematics that a student's image of himself/herself, i.e. self-confidence, is self-fulfilling. As Cangelosi [19] explains, solving a mathematics problem requires students to work through perplexing moments. Students who are not confident in their mathematical abilities tend to stop working as soon as they become perplexed, while more confident ones tolerate perplexity longer, and thus are more likely to continue their work.

The increasing level of difficulty in problems intends to make students selfconfident. While they start from the easiest ones, and gradually progress to more difficult ones, they experience that they are able to solve mathematics problems. So it is not surprising that many students mentioned this feature as a positive characteristic of the textbook:

Problems get more difficult gradually, so they help in understanding the

$$
\text { topic from step to step. (a year } 9 \text { student) }
$$

To help students get over instances of being stuck, the book gives advice on how to proceed when they do not immediately see the solution of a problem.

\section{Way of learning}

The term learning styles includes cognitive styles, the way students process information and construct knowledge, and learning preferences, their favoured way and setting for learning [20]. 
Cognitive styles are distinguished from two main aspects. One is the extent of field dependence. Field-dependent people perceive a pattern as a whole, while field-independent people perceive separate parts of a total pattern. As mathematics needs a greater amount of analytic thinking than of the holistic type, it is usually easier for field-independent learners [20]. The textbook, however, makes many connections within and outside mathematics, and often sets a reallife context, which facilitates the subject for field-dependent learners, and creates a balance between the two types of thinking. The other distinction is made between impulsivity and reflectiveness. An impulsive learner works quickly and makes many mistakes, whereas a reflective student works slowly and reliably [16]. To help impulsive students work with fewer errors, the textbook lays great emphasis on checking answers. Besides the usual way of checking by substitution, it teaches them how to check by looking at the magnitude or the measure of the result, and solve a problem in different ways.

Learning preferences concern the preferred learning environment, and the channel through which a student learns best: auditory, visual, or kinaesthetic/tactile. The textbook leaves the auditory channel to the teacher and other students, but makes full use of visuality. It uses many figures to illustrate mathematical content, highlights definitions and theorems, etc. These features were highly praised in student feedback. The kinaesthetic/tactile channel is used due to the learning by doing philosophy, which is most apparent in the availability of preliminary problems before new material.

Study skills mean the ability to learn effectively. Students with different learning styles benefit from different learning strategies, such as drawing diagrams, looking at worked problems, checking answers, etc. Research shows that "the knowledge of how to study is a skill that varies widely among students and needs to be systematically taught" [19].

The textbook uses Pólya's [21] problem-solving methods in order to improve study skills. It teaches conscious planning, and the main steps of problem-solving procedure through examples. As we have already explained, it also gives advice on how to proceed when being stuck, and how to check answers. The book also makes suggestions for how to memorise things, for example use the consonants of a word to memorize the order of the points on the Euler-line ([2], year 10, p. 63).

One would think that communication skills are not so important to be successful in mathematics. However, research shows that verbal skills and mathematical performance are in strong correlation [22]. The assumed reason is that the student needs to understand the problem, and then formulate and word his/her 


$$
\text { "szasz" — 2005/7/4 - 13:47 — page } 49-\# 15
$$

answer well, especially as reasoning is crucial in mathematics. Cangelosi [19] claims that some students have poor communications skills in the language of mathematics, which has to be specially taught to them (such as the vocabulary, language and symbols of mathematics, the way to illustrate mathematical relationships and express mathematical arguments). Another important use of communication skills in mathematics is interpersonal communication, as co-operative problem solving is very efficient from the early school to scientific level.

The textbook teaches mathematical communication skills by clearly explaining definitions and symbols, and showing how to build reasonings and present solutions. On the other hand, it lacks communicative activities, such as tasks suggested for pair work or group work, which could be included in the future.

\section{General factors}

Mathematics is in the centre of debate and research about gender differences [20]. Boys used to perform significantly better in mathematics, which was considered to be related to their better spatial skills, and their being more left brain learners. It is still debated whether boys' better spatial ability is genetic or it is a result of socialisation, but differences in mathematics performance have been greatly decreasing. It is now generally assumed, that if boys and girls get the same amount and quality of teaching and teacher attention, they will achieve on the same level [23]. Hence textbook writers do not need to treat them as having different needs.

The learning of every student is greatly influenced by their social background, which is itself a very complex factor. Children from different families bring different attitudes to school, and they try to meet different parent expectations. Research shows that socioeconomic status has a strong correlation with students' achievement [20]. This is firstly because more educated parents tend to value education higher, and teach more to their students both in academic and in everyday sense, as learning strategies, thinking methods, and an affection for learning. Secondly, students form wealthier families have easier access to learning tools and materials (books, computers, calculators) [19], extra help (private tutors), or an appropriate place to study at. Thirdly, socioeconomic status also generates a corresponding level of expectation from teachers and of self-esteem, which are bound to be self-fulfilling.

The other feature of family background is ethnicity. Students coming from minority groups might have language difficulties, a different background knowledge, and most importantly, different views and expectations concerning school [24]. In Hungary, the greatest minority group is Gypsies, many of whom find it 


$$
\text { "szasz" — 2005/7/4 - 13:47 — page } 50 \text { - \#16 }
$$

difficult to achieve well in school. This is partly because traditions that do not conform to Hungarian school traditions, and partly because of bias towards them [25]. There have been several government measures to improve their schooling since the late $1990 \mathrm{~s}$.

The most recent programme aims at integrating socially disadvantaged students into mainstream schools, which emphasizes the importance of differentiation, the improvement of study skills, and the increasing of motivation [1]. We have described before how the textbook cares for all of these aims. Besides, worked examples help students study at home even if they do not get family help. The authors of the book took the interest of low-income families into consideration, too, keeping its price low by incorporating problems into the students' book instead of compiling a separate problem book.

Special needs students, besides mentally retarded and gifted mentioned before, are students with physical challenges, who can be sensory impaired or physically handicapped, students with behavioural disorders, and with learning disabilities, among which dyscalculia is specifically related to mathematics. In terms of schooling in Hungary, there are special primary schools for most special needs, but those who continue their studies in secondary school do this in the mainstream.

Among students with physical challenges do not need a special textbook, except for the blind, who need the same content (without geometry) transformed to a different medium. If enlarged, the book can be easily handled by students with low vision, because of its clear layout and because figures are always inserted at the exact place they are referred to (not moved to another page for reasons of page-setting). Students with behavioural disorders and learning disabilities benefit most from the following teaching strategies: using visual aids, teaching in a meaningful context, directly teaching problem-solving and learning strategies, moving from the concrete to the abstract, making students talk about their mathematical understandings, providing multiple practice opportunities, constantly monitoring students and giving them feedback [26]. In fact, these are the same strategies that we set out for students in general. Naturally, with learning disabled students there needs to be a greater emphasis on these strategies, in which the textbook is of great help, because it applied them thoroughly and consequently. Learning disabled students will also need more time learning mathematics, but the differentiated curriculum allows for this. 


$$
\text { "szasz" — 2005/7/4 - 13:47 — page } 51 \text { - \#17 }
$$

\section{Conclusion}

The paper examined in what ways and to what extent the mathematics textbook Matematika (Mathematics, Czeglédy, Hajdu, Hajdu \& Kovács, [27]) is suitable for differentiated teaching. The requirements we set for such a textbook were (1) being based on a differentiated curriculum according to the requirements of the two-level final examination of Hungary, (2) giving space for various techniques of differentiation, and (3) suiting a diversity of students. Evaluation was based on student and teacher feedback in course of an experimental use of the textbook, and also on a close examination of the text itself.

We found that the textbook mixed the two main types of curriculum models, the enrichment model by providing enrichment topics, and the differentiated model by offering and clearly signalling different routes through the same material. Ways of differentiation fell into the three main categories of differentiation by content, by way of learning, and by checking and assessment. The textbook was found to support most aspects examined, but the number of open questions, suitable for differentiating by outcome, was considered too little. The diversity of students was analysed through the main categories of mathematical competence, attitude towards mathematics, way of learning and general factors. We found that the textbook was appropriate for students differing in most factors examined, although we missed communicative activities to develop students' mathematical communication skills.

In sum, we found a great amount of evidence that the textbook is an appropriate tool for differentiated education, and we suggest adjusting the deficiencies mentioned in future editions.

\section{References}

[1] Segédanyag a hátrányos helyzetű tanulók integrációs és képességkibontakoztató felkészítésének pedagógiai rendszerének bevezetéséhez, Oktatási Közlöny, August 6, 2003.

[2] I. Czeglédy, S. Hajdu, S. Z. Hajdu and A. Kovács, Matematika, A Felzárkóztatástól a Tehetséggondozásig, Müszaki Könyvkiadó, Budapest, 2003.

[3] P. Vári, PISA-vizsgálat 2000, Müszaki Könyvkiadó, Budapest, 2003.

[4] P. Vári, Monitor '95, Országos Közoktatási Intézet, Budapest, 1997.

[5] I. Czeglédy, Matematika tantárgy mérés 7. osztályban, Miskolci Pedagógus 26 (1990), 10-16. 


$$
\text { "szasz" — 2005/7/4 - 13:47 — page } 52 \text { - \#18 }
$$

[6] I. Czeglédy, Gy. Orosz, T. Szalontai and A. Szilák, Matematika tantárgypedagógia I., Bessenyei György Könyvkiadó, Nyíregyháza, 2000.

[7] C. C. Kulik and J. A. Kulik, Effects of Ability Grouping on Secondary School Students: A Meta-analysis of Evaluation Findings, American Educational Research Journal 19/3 (1982), 415-428.

[8] R. E. Slavin, Achievement Effects of Ability Grouping in Secondary Schools: A Best Evidence Synthesis, Review of Educational Research 60/3 (1990), 471-499.

[9] J. Boaler and D. William, 'We've still got to learn!' Students perspectives on ability grouping and mathematics achievement, in Issues in Mathematics Teaching, (Peter Gates, ed.), Routledge, London, 2001.

[10] L. V. Stiff, Introducion, Reaching All Students: a Vision of Learning Mathematics, in Reaching All Students with Mathematics, (G. Cuevas and M. Driscoll, eds.), The National Council of Teachers of Mathematics, Virginia, 1993, 3-16.

[11] F. Santiago and G. Spanos, Meeting the NCTM Communication Standards for All Students, in Reaching All Students with Mathematics, (G. Cuevas and M. Driscoll, eds.), The National Council of Teachers of Mathematics, Virginia, 1993, 133-145.

[12] R. Strading, L. Saunders and P. Weston, Differentiation in Action: a Whole School Approach for Raising Attainment, HMSO, London, 1991.

[13] S. P. Meiring, R. N. Rubenstein, J. E. Schuktz, J. de Lange and D. L. Chambers, Curriculum and Evaluation Standards for School Mathematics, Addenda Series, Grades 9-12: A Core Curriculum, National Council of Teachers of Mathematics, Reston, Virginia, 1992.

[14] W. B. Hedrick, Pre-service teachers tutoring one-on-one within the school setting, Reading Research and Instruction 38/3 (1999), 211-19.

[15] J. Ainly, Adjusting to the newcomer: Roles for the computer in mathematics classrooms, in: Issues in Mathematics Teaching, (Peter Gates, ed.), Routledge, London, 2001.

[16] L. V. Stiff, J. L. Johnson and M. R. Johnson, Cognitive Issues in Mathematics Education, in: Research Ideas for the Classroom: High School Mathematics, (P. S. Wilson, ed.), Macmillan, New York, 1993.

[17] P. R. Pintrich, Implications of psychological research on student learning and college teaching for teacher education, in: Handbook of research on teacher education, (W. R. Houston, ed.), Macmillan, New York, 1990, 826-857.

[18] A. Ambrus, Bevezetés a Matematikadidaktikába, ELTE Eötvös Kiadó, Budapest, 1995.

[19] J. S. Cangelosi, Teaching mathematics in secondary and middle school: an interactive approach, (2 $2^{\text {nd }}$ ed.), Merill, Englewood Cliffs, 1996.

[20] A. E. Woolfolk, Educational Psychology, (6 $6^{\text {th }}$ ed.), Allyn and Bacon, Boston, 1995.

[21] Gy. Pólya, A gondolkodás iskolája, Typotex, Budapest, 1994.

[22] L. Friedman, The space factor in mathematics: Gender differences, Review of Educational Research 66/1 (1995). 


$$
\text { "szasz" — 2005/7/4 - 13:47 — page 53 — \#19 }
$$

[23] L. Friedman, The space factor in mathematics: Gender differences, Review of Educational Research 66/1 (1995).

[24] R. B. Lewis and D. H. Doorlag, Teaching Special Students in the Mainstream, Bell \& Howell, Columbus, 1983.

[25] I. Liskó, Cigány tanulók a középfokú oktatásban, Új Pedagógiai Szemle (November, 2002).

[26] M. M. Steele, Strategies for helping students who have learning disabilities in mathematics, Mathematics Teaching in the Middle School 8, 140-149.

[27] I. Czeglédy, S. Hajdu, S. Z. Hajdu and A. Kovács, Matematika, A Felzárkóztatástól a Tehetséggondozásig, Müszaki Könyvkiadó, Budapest, 2003.

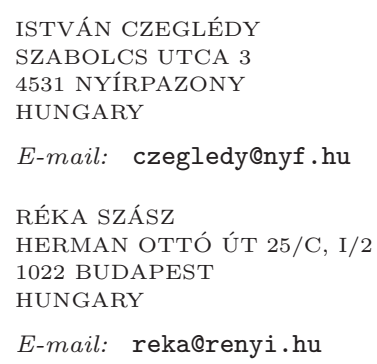

(Received November, 2004) 